\title{
Animating capital: work, commodities, circulation
}

\author{
Maan Barua \\ University of Cambridge, UK
}

\begin{abstract}
Relations between nature and capital have been a longstanding concern in the social sciences. Going beyond antinomies of posthumanist and political economic enquiry, this paper advances a set of relational analytics for incorporating liveliness into critical analyses of capital. Firstly, developing the concept of animal work, it shows how metabolic, ecological and affective labour become a productive economic force. Secondly, animating the commodity, it demonstrates how lively forces influence commodification and exchange, enabling or hindering accumulation. Thirdly, tracking animal circulation, it examines the logics of rendition that transform nonhuman life into capital. In conclusion, the paper develops a relational grammar for anatomizing the nature-capital dynamic, one that reorients the economic to be coconstituted by the ecological from the outset.
\end{abstract}

\section{Keywords}

nature, capital, more-than-human geography, political economy, commodity, labour, value

\section{Animating capital}

This paper examines how nonhuman forces and potentials configure the scope of capitalist accumulation and are a constitutive element of the economic. Nonhuman life is continually brought into the realm of accumulation under contemporary capitalism, from bio-economies molecularizing life through intensification of economic relations (Rajan, 2006), to harnessing living potentials as a speculative source of surplus value (Cooper, 2011), from the capture and reconfiguration of bodies as 'lively capital' (Haraway, 2012; Haraway, 2008), to their circulation as 'animal capital' (Shukin, 2009). Indeed, as work in the critical social sciences is beginning to point out, 'life itself has become a locus of accumulation (Cooper, 2011), with troubling effects on the self-evidence of economic categories. How living capacities and potentials make a difference to political economic organization, or for that matter the very category of 'the economic', thus warrants renewed scrutiny and a need to rethink their scope and ambit.

I emphasize the term renewed, for relations between nature and political economy, like those between culture and economy (Crang, 1997; Barnes, 2005), have never eluded geography. Relational economic geographies at the turn of millennium sought to refigure 'the economic', from notions of being represented through the cultural or opposed to it, to the two being intertwined and inseparable (Amin and Thrift, 2008), calling into question the category of 'the economic' as a stable, singular entity (Thrift and Olds, 1996). Although there was no ecologyeconomy equivalent of the culture-economy debate, ${ }^{1}$ economic geographers have continually challenged the notion of nature as an unproblematic stage upon which the 'real business' of economy takes place. Neil Smith's production of nature thesis, which argued that nature was itself an outcome of (capitalist) economic processes (Smith, 2007), was a radical move that overhauled ontological dualisms of nature as a world outside society (Smith, 2010). Subsequent work building upon this thesis through what has come to be known as 'political 
ecology/economy' (McCarthy, 2012), has made headway into showing how capitalist accumulation is contingent on the appropriation, enclosure and commodification of nature (Harvey, 1996; Heynen et al., 2007; McCarthy and Prudham, 2004). Economic relations, capitalist or otherwise, not just spill over into ecological domains, but are 'embedded' in them (McCarthy, 2012: p.613). Whilst contributions of the production of nature thesis have been significant in charting ecological and corporeal consequences of capitalism, critics point out that the notion of embeddedness in articulating the traffic between ecology and economy is limiting (Thrift and Olds, 1996; Braun, 2008), as it posits nature in a unitary fashion (Guthman, 2011), and places agency squarely on the side of capital (Braun, 2015; also see Castree, 2002). In response, more recent economic geographic work, acknowledging that the 'relationship between categories presumed to be separate and pure are, at best, obfuscatory', has begun to take the 'materiality' of nature seriously (Bakker and Bridge, 2006: p.6). Nonhuman nature might be 'uncooperative' (Bakker, 2003), a source of unpredictability, unruliness and resistance to human action (Bakker and Bridge, 2006; Bakker, 2012), not infinitely malleable but possessing generative capacities confounding efforts to produce nature in particular ways (Bridge, 2011; Prudham, 2003).

There is scope for extending these moves to formulate how capitalist modes of economic organization, and the category of the economic, ${ }^{2}$ might be 'made up' of the nonhuman 'from the outset', rather than merely introducing 'changes into something that exists separately from them' (Braun, 2008: p.669). Here, dialogues with more-than-human geography (Whatmore, 1999; Whatmore, 2002), and cognate developments broadly termed 'posthumanism' (Haraway, 1991; Wolfe, 2010), can be generative. More-than-human geography puts a number of agendas onto the analytical table. It goes beyond merely registering the recalcitrance of the living and material world to emphasize the constitutive force of things in social and political life, a tendency it shares with new materialisms (Braun and Whatmore, 2010a). 'Practical' or 'performative' ontologies are emphasized, where socio-political assemblages are not so much pre-given, but emerge as a result of what people and things do (Bingham, 20o6). Furthermore, notions of skill and knowledge are reworked from being solely human achievements to competencies crossing porous bodies and human-nonhuman divides (Whatmore, 2013; Whatmore, 1997). Whilst these moves have much to offer up for a relational analysis of capital, and for reworking the category of the economic, political economic concerns have remained marginal to its modes of inquiry (Castree, 2002; Braun, 2008).

An emerging body of work, often focused on animal life, is however beginning to tend to nonhuman life as a constitutive dimension of capitalist economies (Collard, 2013b; Collard and Dempsey, 2013; Barua, 2016; Barua, 2017). Intellectually promiscuous and often engaging disparate fields including post-feminist studies of science and anthropology (Haraway, 2008; Porcher, 2014; Shukin, 2009), its contributions have been in three overlapping arenas. Firstly, taking cues from Haraway's observation that 'human labour might only be part of the story' in capitalist modes of production (Haraway, 2008: p.46), it reformulates the category of labour to highlight how animals' productive and reproductive work become vital to generating capitalist surplus (Coulter, 2016; Porcher, 2014). A second impetus is on animal commodities, eliciting both the uneven dynamics through which life is rendered into a commodity, and in turn, the bearings lively potentials have upon processes of commodification (Collard and Dempsey, 2013; Barua, 2017). A third arena of enquiry pertains to animal circulation. Attending to animal mobilities as 'lively capital', it shows how living and material affordances of nonhumans have implications for the itineraries of their realization, consumption and flow (Shukin, 2009; Colombino and Giaccaria, 2016). Taking the constitutive role of the nonhuman seriously, and eschewing the ontological hygiene of an ecology/economy dualism, these interventions pay close attention to the inequalities and asymmetries generated by capital, to which some strands 
of posthumanism and new materialism have been symptomatically blind (Lemke, 2018; Battistoni, 2017).

This paper synthesizes these dispersed strands of work to 'animate' capital: rethinking political economic categories and analysis when the nonhuman is posited as constitutive of the economic, and in parallel, examining the implications of bringing nonhuman life into the locus of capitalist accumulation. This intervention is centred on animal bodies and potentials, which indexes the nonhuman in ways different from other materialities - oil, coal, minerals - that have been the staple of resource geographies (Bakker and Bridge, 2006; Bridge, 2011). Whilst it produces specific iterations of nonhuman space-times and agency, these specifics are deployed generatively, firstly to conceptualize animal work and labour, highlighting its different parameters and forms. The paper then turns to commodities, showing how capitalist accumulation is not indifferent to animal bodies and labour, in fact tapping into their vitality in all sorts of (troubling) ways. The final focus is animal circulation, front-staging the different logics of 'rendering' at work in transforming living bodies into capital. Overlapping rather than discrete, aspects of this triad - work/labour, commodities, circulation - are 'moments' within a wider dynamic of capital (Marx, 1978). Work and circulation as process, and commodity as material embodiment, enables anatomising how capital is animated and animates, and specifying how the nonhuman features at points of this wider dynamic. Together, the triad allows for examining the nature-capital nexus as a totality, synthesizing the dispersed literatures the paper draws from. A brief conclusion highlights the significance of this arena of enquiry, particularly how the analytics developed herein enable grasping capitalism as a set of ecologicaleconomic processes and practices, co-constituted by the plurality (Castree, 1995; Castree, 2002), and innovative potentials of nature from the outset (Braun, 2015), whilst maintaining a critical take on the asymmetries generated by capital's ecological turn (Cooper, 2011; Haraway, 2012; Rajan, 2006).

\section{Animal work}

Concepts of 'animal work' (Porcher, 2015) and 'nonhuman labour' (Barua, 2017), are vital entry points for animating capital. Drawing inspiration from Haraway (Haraway, 2008; Haraway, 2012; Potts and Haraway, 2010) and Ingold's (Ingold, 1983; Ingold, 1988; Ingold and Hallam, 2014) expositions of labour and work as not exclusively human activities, these concepts open up the 'possibilities of forces outside human labour' (Guthman, 2011: p.235), forces that have played a crucial role in the historical development of capital (Hribal, 2003), which the latter presupposes but does not itself produce (Braun, 2015). Whilst critical for rethinking how nonhuman potentials co-constitute the economic, animal work cannot be conceptualized through anthropomorphic extension. As Haraway reminds us, animals 'are paws, not hands' (Haraway, 2008: p.55). Five critical dimensions need careful consideration.

Firstly, intentionality and functionality are immanent in the labour process as opposed to an imposition of prior design upon an external nature - a division Marx introduced in his famous distinction between the work of the architect and that of the bee (Marx, 1976; Ingold, 1983). Secondly, products of labour are ontogenetic. Rather than the hylomorphic activity of making, associated with the manufacture of artefacts or things, production is akin to a process of growth, of setting up conditions within which beings take up their forms and dispositions (Ingold and Hallam, 2014). Its consequence is that distinctions between productive and reproductive labour, long eschewed by Marxist feminists (Hartsock, 1983), become a moot point, enabling processes of nonhuman bodily incorporation and reproduction to be factored into political economic analyses. Thirdly, such labour or work is porous, performed relationally with a suite of other actors cross-cutting animal-human divides, with bearings on the scope and organization of 
economic activity (Porcher, 2014). Fourthly, temporalities of nonhuman labour are rhythmic, emerging from bodily movement and metabolic growth rather than capital's sidereal and chronometric division of the working day (Barua, 2016). Finally, animals do not 'naturally' become labourers and nonhuman divisions of labour are not default, no more than people 'naturally' sell their labour. Rather, an active history of expropriation and exploitation is at play, which forges the very conditions for this category to emerge (Hribal, 2003). These dimensions run through different manifestations of animal work - what I term metabolic, ecological and affective labours - elucidated in further depth below.

How animals labour under industrial conditions, the transformations in their material and sentient lives as a result, and animal contestation to such exploitation are themes gaining traction in geography and the wider social sciences (Coulter, 2015; Porcher, 2011; Gillespie, 2014; Gillespie, 2015; Wadiwel, 2018). A central emphasis here is that animals are workers in the shadows of capitalism: their unwaged labours are rendered invisible, both by working practices of accumulation, and conceptualizations reducing them to raw material (Marx, 1976) or fixed capital (Marx, 1978). Yet, as Porcher and Schmitt's ethno-ethological study of cows in intensive dairy production farms illustrates, work on farms require cows' participation, the ways in which they 'do things ... take decisions and initiatives' (Porcher and Schmitt, 2012: p.43). Cows learn to follow rules that facilitate robot milking, partly influenced by intra-herd negotiations and hierarchies. Conversely, they can adopt deviant behaviours resulting in robot dysfunctions, indicating that the animals have some understanding of how machines work. Automation and drives to increase production, reduce costs and do away with human labour wherever technologically possible' - what would typically be seen as the subsumption of labour by capital - are contingent upon the 'intelligence and affects' cows invest 'in the activity of work' (Porcher and Schmitt, 2012: p.42, p.56).

Nonhuman labour can be further understood as a productive force through ontogenesis: accumulated labour incorporated or grown into the performing body, akin to 'body work' done by dancers, athletes and boxers (Wacquant, 1995), albeit without the same intentionality of entrepreneurship. One can term this metabolic labour: 'emergent ways of fleshy becoming' lying 'at the heart of biocapital, both as commodities and as modes of production' (Haraway, 2008: p.54). The rise of commercial broiler chickens in the 1990s, growing to almost twice the weight of those from the 1930s, in less than half the time and nutrition, is a classic example (Boyd, 2001). Metabolic labour is not only vital for intensification and speedup of commodity production but, from the perspective of capital, transforms one substance into another in a way that anthropogenic machines cannot yet duplicate (Beldo, 2017). Chicken, like other intensively farmed animals (Blanchette, 2015), have to bear the burden of enduring metabolic and reproductive labours, of feeling the effects of cellular processes at rates demanded by capital. The animal body thus becomes an accumulation strategy, where conditions for its growth are intensified to realize relative surplus value. Ontogenesis implies there is more than human inputs involved in value generation (Haraway, 2012; Barua, 2016), and in certain cases even entirely displace human labour (Wadiwel, 2018).

The critical import of metabolic labour is witnessed in at least two related directions. The first entails rethinking primitive accumulation, by extending avenues opened up by Sylvia Federici in her interrogation of the concept from a feminist viewpoint. Federici points to the historical development of new sexual divisions of labour that subjugated women's work and reproductive functions to the reproduction of the work-force (Federici, 2004). Parallels are seen in industrial chicken production, where chicken 'are made hostage to their own reproductive or metabolic labor' (Beldo, 2017: p.119). 'Born to become meat', chicken are kept alive for eight to ten weeks in average, whilst their natural life expectancy ranges from six to fifteen years (Coulter, 2016: 
p.206). Capital is not only parasitic, but commands control over their reproductive and productive labour at ever-expanding scales, to the extent that chicken have become the world's most common bird. Over 6o billion are killed worldwide annually and their fossilized bones have even become a defining feature of the Anthropocene's stratigraphy (Carrington, 2016). Nonhuman labour and concealed practices of exploitation thus offer up a unique perspective to reconsider, to use Noel Castree's evocative term, 'geomaterial' histories of capitalist relations (Castree, 2001), for primitive accumulation runs 'deeper than the enclosure of animals as food sources; it involves splitting apart relationships and knowledges forged out of everyday living together of humans and animals' (Shukin, 2009: p.214).

Secondly, feminist reworkings of primitive accumulation provides valuable correctives to Foucault's abstract notion of biopower, which has gained significant, and at times uncritical, traction in geography. The shift to biopower as evoked by Foucault, Federici argues, needs to be placed in the context of the rise of capitalism, 'for the promotion of life-forces turns out to be nothing more than the result of a new concern with the accumulation and reproduction of labor-power'. Capitalist society seeks to transform life into the capacity to work and into 'dead labour' (Federici, 2004: p.16). From this viewpoint, primitive accumulation has been a universal, albeit aleatory and conjunctural (Read, 2002), process in every phase of capitalist development. However, contrary to Foucault, such histories 'cannot be written from the viewpoint of a universal, abstract, asexual subject' (Federici, 2004: p.16), which, one might extend to say, cannot be written from the exclusive standpoint of a humanist subject. A strong case for such a claim is made by Gillespie (2014) in her analysis of the US dairy industry, where there is a gendered commodification of the productive and reproductive capacities of bovine bodies, resting on a system of sexualized violence. 'A cow's purpose for living is to "stay pregnant" (Gillespie, 2014: p.1329), whilst the animals are prohibited from interacting with and raising their own calves. The demands of industrial production push cows to their (re)productive limit. 'Exhausted from repeated impregnation and milking' (Coulter, 2016: p.206), their bodies undergo a further round of commodification in death: as meat. Males on the other hand are raised for veal, and live short, isolated lives. Selling calves for veal and beef is 'an attempt by the dairy industry to eke capital from what would otherwise be considered a "waste product" (Gillespie, 2014: p.1327). Such commodities contain 'dead' forms of nonhuman labour (Perkins, 2007), which is of equal import as congealed human labour typically posited by political economic straightjackets.

Metabolic and reproductive nonhuman labour opens up underexplored questions, as Negri reminds us, on relations between Foucauldian biopolitics and the real subsumption of labour under capital (Negri, 2017). Marxist political economy points to the real subsumption of nature under capital (Smith, 2007), associated with capital's strategy of intensifying metabolic rhythms, yield and turnover time to appropriate relative surplus value at unprecedented levels, both historically (Hribal, 2003), and in the present (Boyd and Watts, 1997). Foucauldian biopolitics that more-than-human geographies espouse gravitate towards investigating how animal populations are managed through logics of 'improvement', 'purity' and 'security' (Biermann and Mansfield, 2014), sometimes missing out on the 'nauseating recursivity' to the logic of subsumption where 'capital becomes animal, and animals become capital' (Shukin, 2009: p.16). Chiasms constituted through an anatamo-politics of the body and the subsumption of nonhuman labour by capital indeed warrant further investigation if one is to better understand how life itself becomes a locus of accumulation.

However, not all life is subsumed by capital: life/time can be, and remain, extrinsic to capitalist production. Animal work in the form of ecological labour is one such example. Characterized not so much by the reproduction of future workers for a capitalist system, but an eco-social 
reproduction necessary for the regeneration and renewal of ecosystems (Coulter, 2016; Battistoni, 2017), ecological labour points to livelihood processes cutting across species divides. Work done by insect pollinators such as bees, on which a third of global agriculture depends (Kosek, 2010), is illustrative. In contrast to highly orchestrated work and intensively metabolized labours of farm and industrial animals, ecological labour is largely contingent upon an organism's quotidian rhythms and ethological propensities. It is often in their demise or absence that effects of hidden ecological labours - which the biogeographer E.O. Wilson famously described as 'the little things that run the world' (Wilson, 1987) - are felt. Honeybee colonies in North America have declined by as much as 50\%; similar global trends have induced what some call a 'pollinator-mediated food crisis' (Ghazoul, 2005). Pollinators are increasingly being framed as providers of 'ecosystem services' (Daily, 1997), with a range of metrics, indices and modalities of accounting bringing them into the realm of economic calculability as 'natural capital' (Helm, 2015). Work done by pollinators are reified in an 'abstract global ledger that can be essentialised into newly conceived exchangeable parts' (Sullivan, 2013: p.202), monetizing the conditions of life and creating a 'biospheric service economy' (Battistoni, 2017: p.9). At its extreme, coupled with 'willingness to pay for services' arguments of neo-classical economics, they are put on the global market through 'biodiversity offsetting' schemes (Bonneuil, 2015; Dempsey, 2016).

Ecological labour, enacted through 'a human-nonhuman working assemblage' points to a different 'political entomology' at work (Kosek, 2010: p.669), for natural capital is not just contingent upon eco-social reproduction but constituted by it (Battistoni, 2017). Costs for replacing bees' unwaged ecological labour with human labour can run into billions of dollars for relatively small regions (Allsopp et al., 2008), although undervalued (Breeze et al., 2016), and even relegated 'by willingness to pay' approaches (Battistoni, 2017). Pollinator declines in the US have led to the emergence of 'rent a hive' schemes: orchards pay up to US\$200 per hive for bees' labours in pollination (Kleinman, 2016). In India, poor regulation and a large informal labour market, has manifested in child labour carrying out cross-pollination in cotton farms. Young girls, paid below minimum wage, predominantly perform such regenerative work as 'the task requires 'delicate hands" (Nagarajan, 2015: no page). Conceptualizing animals as colabourers and their activities as ecological labour, as opposed providers of 'services' or a stock of 'natural capital', is not the mere replacement of one metaphor by another. Rather it is about recognizing their material and political effects, given that declaring nature 'capital' is already a politically significant choice. Ecological labour introduces a critical edge to understanding what constitutes the economic. It raises important questions about appropriate relationships of compensation, care and value overridden by attempts to salve the contemporary biodiversity crisis through market mechanisms (Battistoni, 2017).

A final dimension of work carried out by animals is affective labour, which has gained significant precedence in contemporary capitalist economies. As Hardt and Negri (Hardt and Negri, 200o: p.292) point out, 'affective labour of human contact and interaction', witnessed in say health services and the entertainment industry, 'is focused on the creation and manipulation of affect'. 'Labour in the bodily mode', affective labour is 'immersed in the corporeal, the somatic' but its products are intangible. Extending this analysis to account for affects permeating and swirling between human and nonhuman bodies, Plourde's (2014) work on 'cat cafes' in post-3/11 Japan shows how customers increasingly desire new forms of intimacy and social connectedness to cope with a stressful, recessionary atmosphere. Cats' homeothermic bodies and soft, furry coats afford soothing, tactile encounters. Their desirability has sparked a global retail phenomenon, spreading from San Diego to Singapore. Yet, affective labour can be taxing for the felids. Overriding their nocturnal habits, consumer demand results in sleeping animals being regularly woken up and placed on waiting customers' laps during the day (Plourde, 2014). Affective 
labours are also harnessed in spaces of captivity, particularly those contingent upon showcasing animals. Work on 'celebrity' bull elephants in southern India shows how spectacular-specular consumptive experiences of encountering elephants is contingent upon a careful micropolitical channelling of affect and a concomitant, if invisible, disciplining of proboscidean bodies (Barua, 2016). Elephants are made to interact with enthused publics and participate in over two hundred processions and religious ceremonies annually, in part fuelled by rental fees exceeding US $\$ 1,000$ per day that renders their captive lives into a lucrative business. Celebrity elephants are often bored and depressed in captivity. Individuals are even known to kill their handlers, indicating that affective labour in captivity is fraught with asymmetries.

In summary, metabolic, ecological and affective labour enable a critical exegesis of what Marx famously called 'the hidden abode of production' as well as the realm of reproduction beyond it (Battistoni, 2017). They bring hidden geographies of expropriation to the fore, hidden because they cease to be 'real work' in the money-economy (cf. Federici, 2004), whilst geomaterial histories of animals in economic production point to otherwise (Hribal, 2003). The nonhuman is rendered visible as a constitutive element of the economic. To evoke animal work however is not to efface the difference between human labour and other forms, but to account for a number of living potentials that capital parasitizes upon in its quest to expand and reproduce. Labour, as Marx (1976: p.287) emphasized, is a process but rendered into a static 'thing-like' character through market objectifications. To examine these other moments in which capital is 'lively', the next section will turn to the material embodiments of animal labour in its commodity form.

\section{Animal commodities}

Animals are at once workers and commodities. A central point of analysis in the cultureeconomy debate (Amin and Thrift, 2008), and a persistent concern within geographies of nature (Castree, 2003), commodities have been vehicles for exploring the turbulent relations between nature, culture and the economic (Bridge and Smith, 2003). Lurking within this turbulence however, is an under-acknowledged concern, raised by Whatmore (Whatmore, 2002: p.118) almost two decades ago, that 'lively currents in the inter-corporeal commotion of commodities' are 'much more than simply a "traffic in things" set in motion by exclusively human subjects'. Her emphasis on the affectivity of things on their own account, their capacity to resist and deflect the course of human action and design, has been extended by recent scholarship on animal commodities, a body of work that brings metabolic potentials and corporeal compulsions into the fray, whilst examining how liveliness makes a difference to the logics of accumulation.

Initial interventions in this regard pertained to conceptualizing animals commodities as 'interactive' and 'sentient'. Moving beyond straightjackets of how marketization and alienation flattens and deadens nature into abstract objects, the former retrieved the role of embodied relations with the animal/commodity, suggesting these relations are vital for the creation of economic value (Duffy, 2014). Work on sentient commodities, predominantly focusing on livestock (Wilkie, 2005; Wilkie, 2015), sought to recast the commodity as one aware of its environments, corporeal sensations and relations to others, thereby foregrounding 'empirical, attitudinal and affective elements of stockmanship' missed out when the focus is on abstraction and exchange (Wilkie, 2015: no page). These interventions have been critically expanded through a body of work on 'lively commodities', which recovers a role for nonhuman animals as active participants in co-constituting the fabric of the economic, without fetishizing the commodity all over again (Collard, 2013b; Collard and Dempsey, 2013; Barua, 2016). A central axis of these commodity geographies is that 'vital or generative qualities' of the animal 
commodity are seen as fundamental to valorization, productive of 'capitalist value as long as they remain alive and/or promises future life' (Collard and Dempsey, 2013: p.2684). Lively commodities are counters of circulation, exchange and consumption whose value derives from their status as living beings. Three themes in this literature - commodity potentials, biographies and surfaces - provide important cues for analyzing the dynamics of lively capital.

The first - commodity potentials - specifies how the material-semiotic animal commodity has bearings upon commodification practices. It harks back to a long-standing geographical insight that 'capitalist commodification is not necessarily indifferent to the natures being commodified' and that 'the process of capitalist commodification (or its effects) might operate rather differently depending on which particular natures are being commodified' (Castree, 2003: p.275). Collard and Dempsey (2013), in their seminal paper on lively commodities, point to two important scales at which commodification occurs. In the exotic pet trade, for instance, the lively commodity is an individualized, encounterable animal. Ethological dispositions of the animal commodity, including its domesticity, ability to interact with prospective owners, 'is central to their construction as valuable objects, and thus productive of their economic value' (Collard and Dempsey, 2013: p.2687). Equally, corporeal affordances such as homeothermy which prompts haptic interactions, and forward-facing eyes that enable intensive, desirable encounters to be staged, play a vital role, as shown in instances of lions and elephants in political economies of ecotourism and biodiversity conservation (Barua, 2016). These potentials, that appear charismatic to publics, are frequently amplified and channelled by marketing campaigns (Barua, 2017). On the other hand, bioeconomic circuits mobilizing ecosystem services or natural capital gravitate towards the reproductive and the aggregate (Collard and Dempsey, 2013). Animal work, particularly ecological labour, is the target of commodification as illustrated in the example of bees discussed earlier. At aggregate scales, corporeal affordances seem to matter less than the labour or eco-social reproduction animals perform as collectives.

In many instances commodification can in fact produce lively potentials. Breeding docile animals for the pet trade, that has resulted in a form of 'anthropomorphic selection' (and severe welfare problems in companion animals) (Serpell, 2002), is a case in point. A recursive relation between liveliness and commodification becomes apparent, pointing to the need to examine bio/anatamo-politics and capital in conjunction, an argument flagged up earlier in the paper and whose importance cannot be reiterated enough (cf. Federici, 2004). Attending to commodity potentials and the anatamo-politics of their production would open up new ways to understand how and why particular nonhuman bodies are produced and the specific form they take on as lively capital.

A second theme involves commodity biographies: the social and material lives that 'take shape as a result of the diverse encounters between people and things' (Bridge and Smith, 2003: p.259). Examining commodity biographies in the context of lively capital is to put an equal emphasis on the bio - attending to material and ecological lives of animals as they move and undergo transformations when commodified. Tracking biographies is crucial as things and animals do not have a commodity status always and already built into them. The question at stake, as Castree reminds us, is not 'what is a commodity?' but rather 'what kind of characteristics do things take on when they become commodities?' (Castree, 2003: p.277). Animals, when for instance circulating as lively commodities in the pet trade, can have a 'wild life', inexorably linked to their own kin and ecological relations, and a 'commodity life' where such relations are severed and ties with humans intensified (Collard, 2013b), often involving fraught affective labour. Equally, biographies need to be situated in historical material terms for lively potentials are mutable over time, appearing as value-bearing life at very specific junctures and through highly contingent relationships. Work on animals' histories point to this mutability and 
contingency (Barua, 2017). In colonial India, lions were hunted game and prized trophies; archival records show how they had resorted to becoming elusive and nocturnal, living a 'trophy life'. Baiting for ecotourism, and commodification of human-lion encounters, resulted in dramatic ethological changes, including docility and daytime predation, resulting in the emergence of a 'commodity life'. However, such transformations were not linear: during periods of drought lions became aggressive, altering their docile ethological dispositions towards people. The potential 'to deterritorialize capital's capture of their living labour' remained immanent to the lively commodity's quotidian rhythms (Barua, 2017: p.281).

Whilst commodification is a 'moment' in the reproduction and expansion of capital, commodity biographies also signpost resistances to the capture of life. Many of these acts emerge as 'a surprise', but litter the space and places of animal lives 'at different moments in the commodification process' (Gillespie, 2015: p.117-118; Lainé, 2016; Hribal, 2003; Wadiwel, 2018). Animals' status as property or commodity is often the central context for such resistance. The latter can include a refusal to work or to reproduce, unexpected behaviour and even escape from enclosure (Wadiwel, 2018). Such moments of resistance are 'threats to the efficient accumulation of capital,' becoming 'practical problems to be prevented or mitigated through breeding and spatial or bodily management' (Gillespie, 2015: p.126). It is partly this inability to see acts of nonhuman resistance as agential rejection of the economic structural conditions that renders animals ownable and commodifiable. Equally, commodity biographies are fluid: they also point to processes of decommodification where socio-ecological relations severed by commodification are re-established, as in the case of 'rehabilitation' of animals in the exotic pet trade and dairy industry (Collard, 2013b; Riley, 2011), where agency is primarily human, and deterritorialization of commodity life through recalcitrant and slippery acts where nonhuman agency gains primacy (Barua, 2017). The establishment of large populations of feral parakeets in European cities - escapes from captivity and trade networks - is compellingly illustrates the latter. Parakeets 'officially valued' as commodities are deemed a 'threat' (Collard and Dempsey, 2017) once they elude captive/trade networks and become invasive. Similarly, recommodification remains imminent, particularly for rehabilitated creatures that lose productive value. Commodity biographies thus suggest that orientations of nonhuman life in relation to capitalist value are fluid and topological, rather than constituted by clear-cut typologies.

Thirdly, work on lively commodities critically engage with commodity surfaces - the intimate points of encounter between people and animals - and affiliated questions of commodity fetishism that mask geographies of exploitation. An important thrust has been on the encounter: forms of attachment emerging through sensory and affective registers (Wilson, 2016; Barua, 2015) with direct bearings on a lively commodity's socio-political palatability (Barua, 2016). Encounters, and therefore commodity surfaces, are understood relationally - an animal's lifeworld and behavioural ecology playing an important role in how they take 'grip' (Barua, 2015), or fail to compose mutual worlds (Ginn, 2013), but equally contingent upon geomaterial histories of these relations and stratified dynamics of power (Barua, 2017).

As part of a tripartite structure alongside use and exchange value, others introduce the concept of 'encounter value' to account for animal work and labour in value-added processes (Barua, 2016; Haraway, 2012; Barua, 2015). If value is understood as 'socially-necessary labour time' in its orthodox, anthropocentric version (Marx, 1976), encounter value makes possible articulating a 'unified labor-nature time', where there is a joint production of value by human and nonhuman labour, and consequently, a combined generation of surplus value (Walker, 2017; for a debate, see: Kallis and Swyngedouw, 2017). The logic here is that the work performed by nature - as bodily labour or congealed 'dead labour' (Perkins, 2007) - is part of the value calculus as average 
(human) labour time includes socially necessary amounts of natural 'inputs'. Surplus value is a 'free gift' of extra work time to the capitalist (Marx, 1976), and hence unwaged nonhuman labour embodied in surplus labour time contributes to the production of surplus value (Walker, 2017). The question of what constitutes value, as Foucault's important but not-currently-trending early work showed, has historically been a political rather than purely economic one (Foucault, 1970). Encounter value and unified labour-nature time not only allows for other ways to value nature (Barua, 2016), but provides valuable correctives to the accounting of neo-classical economics that, as the earlier example of pollination highlighted, typically under-values the work of nature (Battistoni, 2017).

Furthermore commodity surfaces engender a plural and multiperspectival geographical imagination feeding into calls to 'get with the fetish' (Castree, 2001: p.1519). Work on the spectacular traffic in animal commodities shows how encounter value is pivotal to the proliferation of consumptive experiences, from viewing wildlife (Duffy, 2014; Barua, 2017), to intimate interactions in captivity (Parreñas, 2012; Plourde, 2014), reinvigorating 'Marx's insight that the commodity is charismatic in its lifelike effects' (Shukin, 2009: p.19). Organisms' 'nonhuman charisma' is mobilized to render life for sale, bestowing 'consumptive experiences with a unanimous and trans-historical rationality' (Barua, 2017: p.286). But rather than simply reducing affective intimacies to a production of exchange value, getting with the fetish is to pay close attention to trans-actions crossing porous human-nonhuman divides that give encounters their consumptive charge (Barua, 2016). Commodity surfaces direct attention to the tensions and relations between species (animate life) and specie (metal coinage), nudging analysis towards what happens when 'value becomes flesh again' (Haraway, 2008: p.45).

In summary, relational understandings of commodity potentials, biographies and surfaces provide valuable correctives to overtly economistic or cultural approaches to commodity geographies. The alternate grammar that emerges is cognizant of how practices and processes of commodification operate differently depending on what ecologies are being commodified (Collard and Dempsey, 2013), point to how liveliness can generate resistance and pose threats to the accumulation of capital (Barua, 2017; Gillespie, 2015), and provide insights on the role of nonhuman in and the generation of surplus value (Barua, 2016; Walker, 2017). To further articulate how, and at what moments, living bodies are transformed into capital, the next section moves from material embodiment to process in the form of animal circulation.

\section{Animal circulation}

Whilst labour and commodities enable relational understandings of production and exchange, circulation provides crucial further insights into the dynamics of lively capital as it enables conceptualizing animals as value in motion. In contemporary economies, animals are trafficked as 'wholes': 'simultaneously biotechnologies and workers in several kinds of material-semiotic reality'; and as 'parts': set into motion as 'reagents, tools and products' (Haraway, 2012: p.104105), each with their concomitant geographies of consumption, realization and valorization. Whilst work on animals and mobility tends to focus on parts (Cresswell, 2014), as they potentially 'have much more work in lively capital' than whole animals (Haraway, 2012: p.105), an exegesis of circulation needs to consider both, as the dyad provides fresh avenues for thinking about lively capital in ways that does not rest on a division between the ecological and the economic.

A key concept for thinking through the dynamics of circulation is 'rendering' (Shukin, 2009; Parry, 2012). Rendering implies bringing something into a new form, and in various circuits of capital, animals are brought forward as life from which value can be extracted. In the case of 
'whole' animals, rendering often involves mimetic re-enchantment, an imitation or translation of animals into another medium where their vital and generative qualities are amplified and creatively re-processed in economically productive ways (Shukin, 2009). The craze generated by anthropomorphized meerkats - brand ambassadors for a price comparison website - is illustrative. A playful pun on 'meerkat' (comparethemeerkat.com) and 'market' (comparethemarket.com), coupled with giving the animal the character of a Russian aristocrat, generated 3.6 million hits and more than doubled customer traffic and sales in a matter of months (Brown, 2010). Rendering not only puts animals in circulation in altered materialsemiotic registers, but show how those alterations endow new meanings and speed up commodity consumption. Rendering can also entail the distillation and recycling of animal remains (Shukin, 2009), or the creation of new cell lines that grow, differentiate and move externally (Parry, 2012). The circulation of 'part' animals is thus critically dependent on rendering, transforming the animal body into an accumulation strategy or returning its waste remains into another round in the marketplace.

Dual processes of rendition and circulation have parallels with what Marx calls the metamorphosis of commodities'. Commodities, Marx argues, 'pupate': transforming from one form to another during the course of circulation (Marx, 1976: p.204). There is thus a vitalist tendency in Marx's analogy of metamorphosis, which provides a productive avenue for bringing work on animal mobility into conversation with political economy. As the second volume of Capital pertinently reinstates, what is critical in processes of circulation is 'not primarily the form of the act, but rather its material content' (Marx, 1978: p.110). Ethological dispositions, animals' corporeal affordances and collective potentials, economic dimensions of which were previously outlined, become important, enabling geographers to attend to the circulation of animals as lively capital rather than relegating them to the world of purely economic cargo.

There are distinct geographies to such rendition and circulation. An arena of productive future work would entail tracking the 'lifecourses' of animal circulation: the spatial and temporal journeys of whole-bodied organisms, semiotic renditions and bodily derivatives (Parry, 2012). As opposed to the abstract notion of a circuit, the term lifecourse encapsulates both the social and spatio-temporal itineraries of animal circulation, as well as the living potentials that have bearings on these itineraries. Very different, and enlivened, geographies of resource use and consumption come to the fore as a result. Take the case of the Giant Panda, an animal that has become 'cosmopolitan' (Barua, 2014), no longer confined to its native home in China, but present the world-over in zoos and captive breeding centres (Nicholls, 2011). The traffic in pandas, initially in the form of specimens in the late $19^{\text {th }}$ and early $20^{\text {th }}$ centuries, and as live animals since the 1930s, resulted in the animal's meteoric rise from an obscure creature to a global icon (Songster, 2004). Distanciated and translocal geographies of circulation generated new knowledges of the lively commodity. Novel spaces of encounter were, and are continually opened up, enabling diverse publics to get in touch' with the Panda and learn about its plight in the wild. Equally, the affective labours they perform become vital for the political economies of zoos. In 2011, the arrival of two animals in Edinburgh zoo, loaned from China for a hefty sum of $£ 640,000$ per annum, rescued the institution from near bankruptcy. Visitation rates doubled and the zoo's income jumped to nearly $£ 15$ million (Anon., 2013). As lively capital, Pandas catalyze a range of other consumptive exchanges. Edinburgh zoo's retail and merchandize outfit benefited from the 'panda effect', registering significant increases in sales. Panda loans also opened up a range of promissory material flows fraught with their own environmental consequences: animals sent to Canada was in return for oil (Collard, 2013a), whilst those given to Edinburgh was in lieu of a $£ 2.6$ billion contract of supplying salmon meat, Land Rover cars and petrochemical technology (Buckingham et al., 2013). 
Lifecourses of bodily derivatives on the other hand have heterogeneous corporealities. What may at one point in time be viewed as completely inalienable, for instance organs or genes embedded in the body, may later be extracted and even circulated as counters of exchange (Haraway, 2012). Such lifecourses become evident in Colombino and Giaccaria's analysis of cattle as 'mobile wealth' (Colombino and Giaccaria, 2016). Building upon Marx's view that cattle are both 'fixed capital' as draught animals, and 'circulating capital' fattened, slaughtered and materially rendered into a product for consumption and exchange (Marx, 1978), their emphasis is on livestock, exploring ways in which the 'mobile' and the 'living' dimensions of capital relate to one another. In the context of beef production, the passage from capital to commodity, they argue, involves renditions that transform 'flesh into meat, (living) animal capital into (dead) animal commodity' (Colombino and Giaccaria, 2016: p.1049). What is at stake in lively capital, as incorporated value in motion, is not just human labour, as Marx took great pains to show when pointing to the fetish character of money capital (Marx, 1981), but living/dead forms of nonhuman labour as well. Following Wadiwel (2018; p.535), one could further argue that lively capital involving nonhuman labour leads to a breakdown of the rigid distinctions between constant and variable capital, for animals 'reproduce their own value in themselves (as a raw material)' whilst simultaneously doing labour.

In other instances, through technologies enabling 'life' to be extracted from the body (Parry, 2012), rendering can entail a passage from living capital to living commodities Colombino and Giaccaria show how advances in insemination and cryogenic techniques convert bulls' semen into 'bankable, mobile, lively commodities ... increasing the speed and extending the spatial and temporal reach of the reproduction of (live)stock' (Colombino and Giaccaria, 2016: p.1049). Such molecularization of life generates reproductive capital alienated from the body (Haraway, 2008). Eventually, when bulls' virility begins to decline, they are sent to slaughter and rendered into a number of other products, including leather, cosmetics and glue (Gillespie, 2014). Whilst bull semen is material and its potency as capital has largely to do with reproduction, the logics of rendition concomitantly work in representational terms to foster accumulation. Bulls' posthumous liveliness are advertised through images of spectacular individuals, whose potential in fostering consumption and exchange, are primarily affective (Colombino and Giaccaria, 2016). At what point animals exist as 'raw material', as workers or reproductive labour, or as affective commodities and consumable 'products' are complicated by material and semiotic processes of rendering. They point to the need to be attentive to the rhizomatic geographies lifecourses take, transgressing spatio-temporal boundaries of more-than-human whole organisms' lives/deaths.

Liveliness also has bearings upon the circulation of animal capital: whether it flows with velocity or if it is rendered viscous. The latter is often witnessed in whole-bodied organisms, where a range of political, ecological and material constraints restrict their movements and flow (Barua, 2016). Work on lions in political economies of ecotourism show how a number of cultural and ecological factors work to prevent translocations to other sites where new consumptive encounters can take hold (Barua, 2017). Viscosity also speaks closely to the turnover of lively capital. For animals such as pandas, that fare poorly in captivity (Swaisgood et al., 2003), reproduction is slow and the ability to proliferate and start new rounds of accumulation in other spaces limited. In fact, the past few decades has seen considerable economic investment in panda captive breeding science to increase reproductive success, which has spurred the circulation of animals worldwide (Nicholls, 2011). The same holds for a number of other wholebodied organisms enrolled in political economies of ecotourism and biodiversity conservation where logics of generating an economy of the encounter spurs animal circulation (Barua, 2016). Whilst Marx argued in the second volume of Capital that use values become important from the standpoint of circulation (Marx, 1978), we might point to the role of encounter value in the 
lifecourses of lively capital for what is at stake are 'multiple, nonlinear times of many natural entities', how they 'survive and reproduce' (Castree, 2002: p.138).

'Part' animals or bodily derivatives, from capital's viewpoint stripped off the cumbersome assemblage of the animal body, have greater velocity provided the infrastructure for their circulation is in place. Here, animal labour, essential for reproduction of the circulating part, is not incorporated, but what one might term 'excorporated'. As a consequence, animal tissues and sperm become 'hypermobile', circulated with great ease and at high speed, distributed in altered forms along complex pathways to multiple recipients at different times and locations across the world (Parry, 2012). There is also a concomitant 'speed up' in turnover time once life is excorporated as reproductive cycles of the part become shorter. Such generation of life forms not only entails autonomy, but is a form of primitive accumulation where animals are enclosed from their body part and are made to 'live and die for abstract capital' (Shukin, 2009: p.214). Biomobility produced as a result can become footloose, capable of entering into expanding markets on their own terms.

Increasingly, the autonomy and speed-up of animal circulation has begun to take the form of spectral traffic, where movement in different modalities of animal life and death is replaced with freight in images and virtual bodies giving rise to an economy of appearances (Shukin, 2009). Animal renditions entail shifts from the biological to the affective giving rise to 'spectacular accumulation', a process of valorisation involving 'spectacles' where nature is increasingly mediated by fantastic images monopolising production and intensifying banal consumption (Barua, 2017). The logics of rendition visually and semiotically distil nonhuman labours performed by animals to generate a specular currency of encounters, often reinforced through branding, marketing and celebrity endorsement. Here, the animal is charismatic in its lifelike effects, effects that are fetishistic, as social, more-than-human relations of labour producing specular encounters are literalized (Shukin, 2009). Spectacular renditions are frequently 'recombinant', involving a bricolage of bodies and ecologies separated in time and space to make animals even more appealing. For instance, ecotourism projects in India deploy images of African lions, typically felids with bigger manes than their Indian counterparts, for affective, face-to-face encounters to take grip. Through circulation, such images amplify consumption (Barua, 2017). Spectral traffic, replete with frontier orientations, has dynamic spatial effects. Promissory moves to relocate lions to new sanctuaries in India led to a threefold rise in real estate prices as corporate interest in ecotourism was invigorated by potential future encounters with the charismatic commodity (Barua, 2016).

Branding and advertisement in fact control mimesis in the interests of reproducing capital (Shukin, 2009), and 'more spectacular the conjuring the more possible an investment frenzy' (Tsing, 2004: p.84). However, animals can 'suffer the double binds of representation' when the charisma that excites capital is mobilized (Shukin, 2009). They are unable to challenge the desiring gaze (Davies, 2000), and feral characteristics that threaten accumulation get excluded or ironed out. Work on the deployment of elephants to generate conservation funding, for instance, shows how micropolitical orchestrations of their aesthetic charisma to appeal to donors masks asymmetries of human-elephant relations on the ground, where crop-raiding by elephants can be rampant, the costs of which are disproportionately borne by the rural poor (Barua, 2014).

Circulation and mobile wealth thus opens up the heterogeneous geographies of lively capital. Tracking itineraries of animal wholes/parts, and front-staging the role of living/dead nonhuman labour in their (re)production, allows for a very different analysis of the dynamics of value creation, exchange and realization than those on record in conventional analyses. 
Conceptualizing these itineraries to be 'lifecourses', as opposed to abstract 'circuits', muddies traditional distinctions between fixed/circulating and constant/variable capital. Alternate grammars and methodologies for analysing how capital is animated, and animates, come to the fore, rendering visible links between the affective and the material, between circuits of value, meaning and matter. Animal circulation, the logics of rendition and tracking lifecourses are likely to be arenas of productive future scholarship, for a richer iteration of the economic and how it is constituted by the ecological from the outset.

\section{V: Conclusions}

Animal work, commodities and circulation, as specific 'moments' of lively capital, provide a conceptual anatomy for grasping its dynamics. Both individually, and as a triad, they frontstage the productive force of nature and enable a relational analysis of the nature-capital nexus. Animal work, although unrecognized and undervalued in formulations of the economic, makes evident how metabolic, ecological and affective dimensions of nonhuman labour are integral to the reproduction of capital, in both its production and commodity forms. Nonhuman labour, as a productive force, provides valuable correctives to the human exceptionalism of the 'production of nature' thesis (Smith, 2010), which gave primacy to human labour and on many accounts failed acknowledge the constitutive role of forces outside it (Guthman, 2011). Metabolic, ecological and affective labours make up economic production, not just introduce recalcitrance and unruliness to it.

As this paper has shown, their implications on commodity geographies (Castree, 2003; Bridge and Smith, 2003), are both conceptually and empirically significant. Not only do nonhuman potentials and forces have bearings upon commodification practices, and are at the centre of what undergoes transformations when commodified, they enable reconceptualizing value and surplus such that animal work and labour become part of the analytical equation (Walker, 2017; Barua, 2017; Haraway, 2008). Animal circulation, by tracking heterogeneous, mobile lifecourses, allows one to interrogate the dynamics of valorization. At what points do animals count as labour or as commodities, their differential geographies when set in motion as wholes or as parts, and whether it is in a living or dead form in which value is realized or destroyed, all become salient to the analysis. There is indeed traffic between this triad, as the previous sections have highlighted, but when taken together, they demonstrate how lively capital, as a set of material embodiments and flows, is constituted.

At a broader level this endeavour to 'animate' capital brings onto centre stage relations between the economic and the ecological. If earlier relational geographies challenged a unitary economic logic to emphasize the co-fabrication of the cultural and economic (Amin and Thrift, 2008; Barnes, 2005), what becomes evident here is how the economic is configured by, and dependent upon, more-than-human processes and relationships which remake and regenerate the world. This articulation challenges both the neoclassical iteration of 'internalizing' natures 'external' to the economic, as well as political ecology/economy's emphasis on the economic being embedded in a unitary ecological base. Rather, the economic and ecological co-constitute one another from the outset. This unsettles the ontological hygiene of the economic, rendering nonhuman potentials as eventful, and as components in the organization of economic activity in their own right. Equally, accounting for the productive force of the nonhuman denaturalizes nature and recognizes its already-economic status as also-political (Collard and Dempsey, 2017; Battistoni, 2017).

If the outlines of an approach for conceptualizing how liveliness makes a difference to political economic, particularly capitalist, organization are beginning to become clear, there are still a 
number of disciplinarily challenging implications and consequences. More-than-human geography, with its emphasis on spaces of embodiment, relation and motion (Whatmore, 1999), has taken up the new materialist injunction of including nonhumans in our political world. It attends to nonhuman difference and agency typically eschewed by political ecology/economy (Braun, 2008; Braun and Whatmore, 2010b). Yet, a critical engagement with capital and how the world is constituted by economic relations has been wanting (see Braun, 2015; Lemke, 2018). At times, a lack of 'familiarity in Marxian political economy' (Harvey, 2010: p.vii), and at other times a wholesale rejection of its analytics compounds theoretical innovation. The relatively poor uptake of Haraway's political economic work and heterodox readings of Marx underscoring themes charted in this paper (Haraway, 2008; Haraway, 1997; Harvey and Haraway, 1995), amidst an otherwise exceptional reception of her oeuvre in geography is symptomatic. Some of the rigid conceptualizations imposed by political ecology/economy, particularly its straightjacket conceptualizations of labour, capital and value, compounds a serious engagement with the constitutive role of the nonhuman in economic processes (Bakker and Bridge, 2006).

Scholars in the past have been cognizant of these limitations and have called for moving beyond the 'false antitheses' of eco-Marxism and actor-network theory, or 'old' and 'new' materialisms for that matter (Castree, 2002). Whilst the author cannot vouch for disciplinary inclinations of others, some of the innovative work discussed here suggest that such a move is not only possible, but is beginning to gain traction. The inspiration for these attempts, stems less from ANT-derived scholarship than a critical impulse within posthumanist geography and feminist studies that ask questions about bodies, reproduction, the commons and appropriation in fresh and challenging ways. Future work will benefit from building upon this to track the heterogeneous and plural entities that produces surplus, participate in and constitute the economic. Animating capital is fertile ground: a concerted effort promises rich dividends for the social sciences.

\section{References}

Allsopp MH, De Lange WJ and Veldtman R. (2008) Valuing insect pollination services with cost of replacement. PLoS ONE 3: e3128.

Amin A and Thrift N. (2008) The Blackwell Cultural Economy Reader. Oxford: Blackwell Publishing Ltd.

Anon. (2013) Edinburgh pandas help zoo to turn around its fortunes. BBC News.

Bakker K. (2012) The "Matter of Nature" in Economic Geography. In: Sheppard E, Barnes T and Peck J (eds) The Wiley-Blackwell Companion to Economic Geography. Oxford: Blackwell Publishing Ltd., 104-117.

Bakker K and Bridge G. (2006) Material worlds? Resource geographies and the 'matter of nature'. Progress in Human Geography 30: 5-27.

Bakker KJ. (2003) An uncooperative commodity: Privatizing water in England and Wales, Oxford: Oxford University Press.

Barnes T. (2005) Culture : Economy. In: Cloke P and Johnston R (eds) Spaces of Geographical Thought: Deconstructing Human Geography's Binaries. London: SAGE Publications Ltd., 61-80.

Barua M. (2014) Circulating elephants: unpacking the geographies of a cosmopolitan animal. Transactions of the Institute of British Geographers 39: 559-573.

Barua M. (2015) Encounter: Living Lexicon for the Environmental Humanities. Environmental Humanities 7: 265-270. 
Barua M. (2016) Lively Commodities and Encounter Value. Environment and Planning D: Society and Space 34: 725-744.

Barua M. (2017) Nonhuman labour, encounter value, spectacular accumulation: the geographies of a lively commodity. Transactions of the Institute of British Geographers 42: 274-288.

Battistoni A. (2017) Bringing in the Work of Nature: From Natural Capital to Hybrid Labor. Political Theory 45: 5-31.

Beldo L. (2017) Metabolic Labor Broiler Chickens and the Exploitation of Vitality. Environmental Humanities 9: 108-128.

Biermann C and Mansfield B. (2014) Biodiversity, purity, and death: conservation biology as biopolitics. Environment and Planning D: Society and Space 32: 257-273.

Bingham N. (2006) Bees, butterflies, and bacteria: biotechnology and the politics of nonhuman friendship. Environment and Planning A 38: 483-498.

Blanchette A. (2015) Herding Species: Biosecurity, Posthuman Labor, and the American Industrial Pig. Cultural Anthropology 30: 640-669.

Bonneuil C. (2015) Tell me where you come from, I will tell you who you are: A genealogy of biodiversity offsetting mechanisms in historical context. Biological Conservation 192: 485-491.

Boyd W. (2001) Making meat: Science, technology, and American poultry production. Technology and Culture 42: 631-664.

Boyd W and Watts MJ. (1997) The chicken industry and postwar American capitalism. In: Goodman D and Watts MJ (eds) Globalising food: Agrarian questions and global restructuring. London: Routledge, 139-165.

Braun B. (2008) Environmental issues: inventive life. Progress in Human Geography 32: 667-679.

Braun B. (2015) New Materialisms and Neoliberal Natures. Antipode 47: 1-14.

Braun B and Whatmore S. (2010a) Political matter: technoscience, democracy, and public life. Minneapolis, MN: University of Minnesota Press.

Braun B and Whatmore S. (2010b) The Stuff of Politics: An Introduction. In: Braun B and Whatmore S (eds) Political matter: technoscience, democracy, and public life. Minneapolis, MN: University of Minnesota Press, ix-xxxv.

Breeze TD, Gallai N, Garibaldi LA, et al. (2016) Economic measures of pollination services: shortcomings and future directions. Trends in Ecology \& Evolution 31: 927-939.

Bridge G. (2011) The Economy of Nature: From Political Ecology to the Social Construction of Nature. In: Leyshon A, Lee R, McDowell L, et al. (eds) The SAGE Handbook of Economic Geography. London: SAGE Publications Ltd., 217-230.

Bridge G and Smith A. (2003) Intimate encounters: culture - economy - commodity. Environment and Planning D: Society and Space 21: 257-268.

Brown S. (2010) Where the wild brands are: some thoughts on anthropomorphic marketing. The Marketing Review 10: 209-224.

Buckingham KC, David JNW and Jepson P. (2013) Diplomats and refugees: panda diplomacy, soft 'cuddly' power and the new trajectory of panda conservation. Environmental Practice 15: 1-9.

Carrington D. (2016) How the domestic chicken rose to define the Anthropocene. The Guardian. London.

Castree N. (1995) The nature of produced nature: materiality and knowledge construction in Marxism. Antipode 27: 12-48.

Castree N. (2001) Commodify fetishism, geographical imaginations and imaginative geographies. Environment and Planning A 33: 1519-1525.

Castree N. (2002) False Antitheses? Marxism, Nature and Actor-Networks. Antipode 34: 111-146.

Castree N. (2003) Commodifying what nature? Progress in Human Geography 27: 273-297.

Collard R-C. (2013a) Panda politics. The Canadian Geographer 57: 226-232. 
Collard R-C. (2013b) Putting Animals Back Together, Taking Commodities Apart. Annals of the Association of American Geographers 104: 151-165.

Collard R-C and Dempsey J. (2013) Life for sale? The politics of lively commodities. Environment and Planning $A$ 45: 2682-2699.

Collard R-C and Dempsey J. (2017) Capitalist Natures in Five Orientations. Capitalism Nature Socialism 28: 78-97.

Colombino A and Giaccaria P. (2016) Dead liveness/living deadness: Thesholds of non-human life and death in biocapitalism. Environment and Planning D: Society and Space 34: 10441062.

Cooper ME. (2011) Life as surplus: Biotechnology and capitalism in the neoliberal era, Seattle: University of Washington Press.

Coulter K. (2015) Animals, Work and the Promise of Interspecies Solidarity, London: Palgrave Macmillan.

Coulter K. (2016) Beyond Human to Humane: A Multispecies Analysis of Care Work, Its Repression, and Its Potential. Studies in Social Justice 10: 199-219.

Crang P. (1997) Introduction: Cultural Turns and the (Re)constitution of Economic Geography. In: Willis J and Lee R (eds) Geographies of Economies. London: Arnold, 3-15.

Cresswell T. (2014) Mobilities III: Moving on. Progress in Human Geography 38: 712-721.

Daily GC. (1997) Nature's services: societal dependence on natural ecosystems. Washington DC: Island Press.

Davies G. (2000) Virtual animals in electronic zoos: The changing geographies of animal capture and display. In: Philo C and Wilbert C (eds) Animal spaces, beastly places: New geographies of human-animal relations. New York: Routledge, 243-246.

Dempsey J. (2016) Enterprising Nature: Economics, Markets, and Finance in Global Biodiversity Politics, Chichester, UK: John Wiley \& Sons.

Duffy R. (2014) Interactive elephants: Nature, tourism and neoliberalism. Annals of Tourism Research 44: 88-101.

Federici S. (2004) Caliban and the Witch: Women, the Body, and Primitive Accumulation, Brooklyn, NY: Autonomedia.

Foucault M. (1970) The order ofthings: An archaeology of the human sciences, London: Routledge.

Ghazoul J. (2005) Buzziness as usual? Questioning the global pollination crisis. Trends in Ecology E Evolution 20: 367-373.

Gillespie K. (2014) Sexualized violence and the gendered commodification of the animal body in Pacific Northwest US dairy production. Gender, Place E Culture 21: 1321-1337.

Gillespie K. (2015) Nonhuman animal resistance and the improprieties of live property. Animals, Biopolitics, Law. Routledge, 137-154.

Ginn F. (2013) Sticky lives: slugs, detachment and more-than-human ethics in the garden. Transactions of the Institute of British Geographers doi: 10.1111/tran.12043.

Guthman J. (2011) Bodies and Accumulation: Revisiting Labour in the 'Production of Nature'. New Political Economy 16: 233-238.

Haraway D. (1991) Simians, Cyborgs, and Women: The Reinvention of Nature., London: Free Association Books.

Haraway D. (1997) Modest_Witness@Second_Millennium.FemaleMan@_Meets_OncoMouse ${ }^{\mathrm{TM}}$ : Feminism and Technoscience., Routledge: London and New York.

Haraway D. (2008) When species meet, Minneapolis, MN: University of Minnesota Press.

Haraway D. (2012) Value-Added Dogs and Lively Capital. In: Sunder Rajan K (ed) Lively Capital: Biotechnologies, Ethics and Governance in Global Markets. Durham and London: Duke University Press, 93-120.

Hardt M and Negri A. (200o) Empire, Harvard: Harvard University Press. 
Hartsock NCM. (1983) The Feminist Standpoint: Developing the Ground for a Specifically Feminist Historical Materialism. In: Harding S and Hintikka MB (eds) Discovering Reality: Feminist Perspectives on Epistemology, Metaphysics, Methodology, and Philosophy of Science. Dordrecht: Kluwer Academic Publishers, 283-310.

Harvey D. (1996) Justice, nature and the geography of difference, Cambridge MA: Blackwell.

Harvey D. (2010) A companion to Marx's Capital: Verso Books.

Harvey D and Haraway D. (1995) Nature, politics and possibilities: a debate and discussion with David Harvey and Donna Haraway. Environment and Planning D: Society and Space 13: 507-527.

Helm D. (2015) Natural capital: valuing the planet, New Haven and London: Yale University Press.

Heynen N, McCarthy J, Prudham S, et al. (2007) Neoliberal environments: false promises and unnatural consequences. Abingdon, Oxford: Routledge.

Hribal J. (2003) "Animals are part of the working class": a challenge to labor history. Labor History 44: 435-453.

Ingold T. (1983) The Architect and the Bee: Reflections on the Work of Animals and Men. Man 18: $1-20$.

Ingold T. (1988) Hunters pastoralists and ranchers: Reindeer economies and their transformations, Cambridge: Cambridge University Press.

Ingold T and Hallam E. (2014) Making and Growing: an Introduction. In: Hallam E and Ingold T (eds) Making and Growing: Anthropological Studies of Organisms and Artefacts. Farnham, Surrey: Ashgate, 1-24.

Kallis G and Swyngedouw E. (2017) Do Bees Produce Value? A Conversation Between an Ecological Economist and a Marxist Geographer. Capitalism Nature Socialism DOI: 10.1080/10455752.2017.1315830.

Kleinman Z. (2016) Can tech keep the world's bees buzzing? Available at: http://www.bbc.co.uk/news/business-37386490.

Kosek J. (2010) Ecologies of empire: on the new uses of the honeybee. Cultural Anthropology 25: $650-678$.

Lainé N. (2016) Conduct and Collaboration in Human-Elephant Working Communities of Northeast India. In: Locke P and Buckingham J (eds) Rethinking Human-Elephant Relations in South Asia. New Delhi: Oxford University Press, 180-204.

Lemke T. (2018) An Alternative Model of Politics? Prospects and Problems of Jane Bennett's Vital Materialism. Theory, Culture E Society DOI: 10.1177/o263276418757316.

Martinez-Alier J and Schlüpmann K. (1990) Ecological Economics: Energy, Environment and Society, Oxford-Cambridge: Blackwell.

Marx K. (1976) Capital: A Critique of Political Economy, Volume I, London: Penguin Books.

Marx K. (1978) Capital: A Critique of Political Economy, Volume II, London: Penguin Books.

Marx K. (1981) Capital: A Critique of Political Economy, Volume III, London: Penguin Books.

McCarthy J. (2012) Political ecology/economy. In: Barnes TJ, Peck J and Sheppard E (eds) The Wiley-Blackwell Companion to Economic Geography. Oxford: Blackwell Publishing Ltd., 612-625.

McCarthy J and Prudham S. (2004) Neoliberal nature and the nature of neoliberalism. Geoforum 35: $275-283$.

Mirowski P. (1994) Natural images in economic thought: markets read in tooth and claw. Cambridge: Cambridge University Press.

Nagarajan K. (2015) The Plight of Cottonseed Workers Reveals Why Child Labour Persists. Available at: https://thewire.in/economy/the-plight-of-cottonseed-workers-revealswhy-child-labour-persists.

Negri A. (2017) Marx and Foucault: Essays Volume 1., Cambridge, UK: Polity Press. 
Nicholls H. (2011) The Way of the Panda: The Curious History of China's Political Animal, New York: Pegasus Books.

Parreñas RJS. (2012) Producing affect: Transnational volunteerism in a Malaysian orangutan rehabilitation center. American Ethnologist 39: 673-687.

Parry B. (2012) Economies of Bodily Commodification. In: Sheppard E, Barnes TJ and Peck J (eds) The Wiley-Blackwell Companion to Economic Geography. Oxford: Blackwell Publishing Ltd., 213-225.

Perkins HA. (2007) Ecologies of actor-networks and (non)social labor within the urban political economies of nature. Geoforum 38: 1152-1162.

Plourde L. (2014) Cat cafés, affective labor, and the healing boom in Japan. Japanese Studies 34: $115-133$.

Porcher J. (2011) The relationship between workers and animals in the pork industry: A shared suffering. Journal of Agricultural and Environmental Ethics 24: 3-17.

Porcher J. (2014) The work of animals: a challenge for the social sciences. Humanimalia: A Journal of Human-Animal Interface Studies 6: 1-9.

Porcher J. (2015) Animal Work. In: Kalof L (ed) The Oxford Handbook of Animal Studies. Oxford: Oxford University Press, DOI: 10.1093/oxfordhb/9780199927142.9780199927013.9780199927148.

Porcher J and Schmitt T. (2012) Dairy cows: Workers in the shadows? Society E Animals 20: 3960.

Potts A and Haraway D. (2010) Kiwi chicken advocate talks with Californian dog companion. Feminism \& Psychology 20: 318-336.

Prudham S. (2003) Taming trees: Capital, science, and nature in Pacific Slope tree improvement. Annals of the Association of American Geographers 93: 636-656.

Rajan KS. (2006) Biocapital: The constitution of postgenomic life, Durham and London: Duke University Press.

Read J. (2002) Primitive accumulation: The aleatory foundation of capitalism. Rethinking Marxism 14: 24-49.

Riley M. (2011) 'Letting them go' - Agricultural retirement and human-livestock relations. Geoforum 42: 16-27.

Serpell JA. (2002) Anthropomorphism and Anthropomorphic Selection-Beyond the" Cute Response". Society $\mathcal{E}$ Animals 10: 437-454.

Shukin N. (2009) Animal Capital: Rendering Life in Biopolitical Times, Minneapolis, MN: University of Minnesota Press.

Smith N. (2007) Nature as accumulation strategy. Socialist Register January: 1-36.

Smith N. (2010) Uneven Development: Nature, Capital, and the Production of Space, London: Verso.

Songster EE. (2004) A Natural Place for Nationalism: The Wanglang Nature Reserve and the Emergence of the Giant Panda as a National Icon, Ann Arbor, Michigan: ProQuest.

Sullivan S. (2013) Banking Nature? The Spectacular Financialisation of Environmental Conservation. Antipode 45: 198-217.

Swaisgood RR, Zhou X, Zhang G, et al. (2003) Application of Behavioral Knowledge to Conservation in the Giant Panda. International Journal of Comparative Psychology 16: 65-84.

Thrift N and Olds K. (1996) Refiguring the economic in economic geography. Progress in Human Geography 20: 311-337.

Tsing AL. (2004) Inside the Economy of Appearances. In: Amin A and Thrift N (eds) The Blackwell Cultural Economy Reader. Blackwell Publishing Ltd: Oxford, 83-100.

Wacquant LJD. (1995) Pugs at Work: Bodily Capital and Bodily Labour among Professional Boxers. Body and Society 1: 65-93. 
Wadiwel D. (2018) Chicken Harvesting Machine: Animal Labor, Resistance, and the Time of Production. The South Atlantic Quarterly 117: 527-549.

Walker R. (2017) Value and Nature: Rethinking Capitalist Exploitation and Expansion. Capitalism Nature Socialism 28: 53-61.

Whatmore S. (1997) Dissecting the autonomous self: hybrid cartographies for a relational ethics. Environment and Planning D: Society and Space 15:37-53.

Whatmore S. (1999) Hybrid Geographies: Rethinking the 'Human' in Human Geography. In: Massey D, Allen J and Sarre P (eds) Human Geography Today. Cambridge: Polity, 22-40.

Whatmore S. (2002) Hybrid geographies: natures, cultures, spaces., London: Sage.

Whatmore S. (2013) Earthly powers and affective environments: An ontological politics of flood risk. Theory, Culture E Society 30: 33-50.

Wilkie R. (2005) Sentient commodities and productive paradoxes: the ambiguous nature of human-livestock relations in Northeast Scotland. Journal of Rural Studies 21: 213-230.

Wilkie R. (2015) Animals as Sentient Commodities. In: Kalof L (ed) The Oxford Handbook of Animal Studies. Oxford: Oxford University Press, DOI: 10.1093/oxfordhb/9780199927142.9780199927013.9780199927116.

Wilson EO. (1987) The Little Things That Run the World (The Importance and Conservation of Invertebrates). Conservation Biology 1: 344-346.

Wilson HF. (2016) On geography and encounter Bodies, borders, and difference. Progress in Human Geography DOI: 10.1177/0309132516645958.

Wolfe C. (2010) What is Posthumanism?, Minneapolis, MN: Minnesota University Press.

'One subdued facet of this debate, however, was about the cultural materialization of the economic (Crang, 1997). Relations between ecology and economy in cognate fields include iterations on natural metaphors in economic thought (Mirowski, 1994) and more broadly the field of ecological economics with its emphasis on energetics (Martinez-Alier and Schlüpmann, 1990).

${ }^{2}$ I recognize that whilst the economy is both an object of analysis and a set of practices, there is no stable entity called 'the economy' or a singular notion of 'the economic' (Thrift and Olds 1996). The primary focus of this paper is on capitalist economies and I remain cognizant that this is not a monolithic entity. 